\title{
The Econometric Analysis of Student Expenditures: A Case Study of Amasya University ${ }^{1}$
}

\author{
Rüştü Yayar
}

\author{
Nagehan Karanfil ${ }^{b}$
}

\author{
Hilal Şeker ${ }^{c}$
}

\begin{abstract}
In this study, the consumption expenditures of the students, one of the important income sources of regional economies, were revealed, and it was investigated that whether these expenditures are in relation with sociodemographic factors or not. Used data was collected via survey study done to the students in Amasya University. The income-expenditure functions of the students, the share of fourteen expenditure groups in total expenditures, and income elasticity were estimated with the help of Engel's functions. Sampling was used for sample selection. SPSS and Eviews Packet Programs were used in data analysis. 717 out of 800 surveys were approved and attached to analysis. 14 expenditure items were formed by based on "classification of individual consumption by purpose". It is also searched that whether the gender of the students; studying in daytime or evening education; getting scholarship or loan; being student in faculty or high school; possession of credit card; studying in medical, social or technical departments; and accommodating in houses or dorms had a meaningful difference on consumption expenditures or not. In the study, while a clear observation related to the marginal propensity to consume of the students in daytime education in Amasya University cannot be stated, that their autonomous consumption is 47,5 TL lower than the students in evening education can be stated. It is also observed that the income elasticity values related to alcohol-tobacco, household goods, hotelrestaurant, chance-games, and sport expenditures are higher than 1, and the income elasticity values related to the other expenditure items are lower than 1.
\end{abstract}

Keywords: Consumption Expenditures, Engel Curve, Income Elasticity, University Student, Amasya University

JEL Classification: D12, 125, C21

\section{Introduction}

The economics trying to meet the unlimited needs of people with limited sources always takes a close interest in how to provide the utility maximization of the consumer under budgetary savings. Such that, consumption and consumption function are one of the basic subjects of microeconomics. In many studies, while consumption function and hypotheses were investigated, income-consumption behaviors for countries or cities were searched in some studies (Altunöz, 2014). Consumption function reveals the mathematical relation between consumption expenditures and income, and meanwhile, it is one of the important indicators in savings in an economy. The marginal propensity to consume of the consumers with different income groups will be also different, which shows that the consumption is essentially based on income. However, it must be stated that in addition to income, such factors as wealth, enjoyment and preferences,

${ }^{a}$ Assoc. Prof., PhD., Gaziosmanpaşa University, Faculty of Economics and Administrative Sciences, Department of Economics, Tokat, Turkiye, rustu.yayar@gop.edu.tr

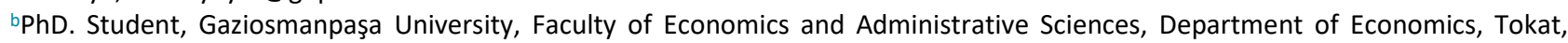
Turkiye, nghnkrnfl@gmail.com

Lecturer, Amasya University, Social Sciences Vocational School, Accounting and Taxation Program, Amasya, Turkiye, hilal.seker@amasya.edu.tr 
price, age, gender, etc. are effective in consumption expenditures. By doing consumption expenditures, individuals not only satisfy their own needs but also increase the income of the producer towards the product group they have consumed. In this aspect, the consumption concerns both the consumers and producers.

As higher education institutions, universities, in addition to being institutions where scientific studies are done and shared, are consumption units with undeniable benefits to economic and social structure of the regions thanks to significant contribution to expenditures and employment. These benefits range far in terms of both social-cultural and economic, and they are integrated into daily life (David, 2003: 9).In this context, the purpose of the study is to examine the consumption expenditures of university students and to investigate whether these expenditures are related to socio-demographic factors. The fact that there was no such kind of study in the literature about Amasya University students motivated us to work on this issue.

In this study, whose aim is to reveal the consumption expenditures of the university students and to investigate whether these expenditures are in relation with socio-demographic factors or not, in the pursuit of introduction chapter, the theoretical framework of the investigation was formed by stating consumption theories available in economic literature. And then, the studies done in both Turkey and the world were revealed by making literature review. Finally, the results obtained through analysis and findings were evaluated.

\section{Theoretical Framework}

Consumption expenditure not only exhibits the utility maximization of the individual, it is also one of the important components of effective demand needed to reveal macro magnitude like employment and national income. In this sense, the consumption expenditures were discussed from macro point of view for the first time by Keynes in his General Theory (1936) work. According to Keynes' Absolute Income Hypothesis, the consumption expenditures are a function of current income.

Keynes' consumption theory can be expressed as functional as follows,

$$
\mathrm{C}=\mathrm{c}_{0}+\mathrm{c}_{1} \mathrm{Y}
$$

The meanings of the symbols in the Equation1are given below:

$\mathrm{C}=$ Total consumption expenditures

$\mathrm{Y}=$ Current disposable income $\left(\mathrm{c}_{0}\right.$ and $\mathrm{c}_{1}$ fixed, $0<c<1$ )

$\mathrm{C}_{0}=$ Autonomous consumption expenditures

$\mathrm{c}_{1}=$ Marginal propensity to consume

Keynes asserts that individuals minimally consume by means of solving their savings or borrowing even in the periods without income. According to Keynes, average of the consumption propensity of the individuals $(C / Y)$ decreases upon the rise in income. Consumption expenditures are stable in spite of the instability of income, and marginal propensity to consumption and marginal saving propensity take fixed value. According to Keynes, when the disposable individual income increases, consumption as well increases; however, when disposable income increases, consumption increases higher than income. Namely, marginal propensity to consume decreases in the long run. Marginal propensity to consume (it also gives the slope of consumption function) demonstrates that one-unit-rise in real income generates consumption expenditure smaller than itself (Ünsal, 2007).

Another hypothesis trying to explain the consumption function in economic literature is Relative Income Hypothesis developed by Dussenbery (1949), there are two different interpretations of the hypothesis. The first one is that the people do not want to give up the consumption level they have reached even if their income decreases. The other one is that average consumption propensity will not decrease in the long run owing to people's keeping up with their own social environments and people's need of influencing their environments through their consumption expenditures (Paya, 2007). Dussenbery 
emphasizes that consumption is more social and behavioral concept, and in a big relation with the society we live in, by trying to associate short and long term consumption functions, and he tried to discuss about the psychological aspect of consumption. Consumption depends on relative income groups not on the current income, and consumption problem can only be solved by investigating the social and psychological essentials of consumption (Dougles and Isherwood, 1999).

The basic starting point of Permanent Income Hypothesis developed by monetarist economist Milton Friedman (1950) is Fisher's intertemporal consumption analysis.

Friedman has established a consumption function such as the following.

$$
\mathrm{C}_{\mathrm{p}}=\mathrm{kY}_{\mathrm{p}}
$$

The meanings of the symbols in the Equation 2 are given below:

$\mathrm{C}_{\mathrm{p}}=$ Permanent consumption expenditure,

$\mathrm{Y}_{\mathrm{p}}=$ Permanent income,

$\mathrm{k}=$ States the portion allocated to consumption of current income.

The aim of Friedman asserting the instability of short-term expenditures is to define the long-term trends of consumption. The consumption of individual is not only depended on the current income but also on the income expected to be acquired. According to Friedman, current income is the basic indicator calculated by the means of adaptive expectations of economic status, wealth, and consumption (Eren, 2001).

Another hypothesis explaining consumption is Life-Cycle (Life Annuity) Hypothesis developed by Ando and Brumberg under the leadership of American economist Modigliani (1963). According to Modigliani, the individuals earn more income in working periods of their life than periods of retirement, and they finance their consumption in the periods of retirement by doing positive saving during the working periods (Ünsal, 2007). In that, consumption is not only a function of current income but also a function of the income expected to be acquired by the individuals through life-long. The individuals arrange both their savings and consumption for long term in order to allocate ideally their consumption throughout their length of life, and they make a decision on their present consumption according to their expectations in the future (Sachs and Larrain, 1993).

RobertHall (1970) asserted Random Walk Hypothesis by discussing permanent income hypothesis in terms of rational expectations, and claimed that it was not possible to propose the changes in consumption. In case of the occurrence of unexpected actions affecting permanent income, some unexpected changes in income occur, which affects the consumption of the people; however, expected changes in income do not affect the consumption of the people (Ünsal, 2007).

Recently, consumption functions have been in the shape of Permanent Income by Friedman and Life Annuity Hypotheses by Modigliani. Accordingly, in the frame of assumption of consumer to foresee the future, the basic variable determining the consumption is wealth, and consumption is an increasing function of total wealth and current income upon taxation. The opinions about the permanent or temporary changes current incomes of the individuals are the main component determining consumption (Eren, 2001).

\section{Literature Review}

In the national and international literature, there are many studies on income-expenditure and the analysis of income elasticity of these expenditure types. In the literature survey, it is seen that there is a greater concentration of students in the national literature in terms of income expenditure analysis.

According to elasticity values calculated 4 expenditure groups by using the data acquired from the surveys implemented in 30 countries, Houthakker (1957) affirmed Engel's Law by reaching the result that the elasticity values of nutrition, clothing, accommodation, and other expenditure groups were approximate to each other's; however, they were not equivalent. 
According to Wilson (1975), the study of Tulsa University's contribution to the local economy has found that students spend $\$ 6400$ a year and the total spending effect is $\$ 25.207 .814$.

Giles and Hampton (1985) estimated the Engel Curve for 8 New Zealand household spending groups and 6 model features were taken into account. Estimated expenditure elasticity and marginal budget allocations are highly insensitive to the choice of functional form in the sample mean. When we look at our study, the income elasticity of the fourteen spending groups have been tried to be estimated with the help of three different functional molds which are most suitable by evaluating the statistical and econometric aspects from the five functional molds with the help of the obstacle functions.

Belaney, Binks, Greenanaway, Reed and Whynes(1992) observed that the highest share of the student expenditures belonged to accommodation with \%28, and secondly, $\% 17$ belonged to nutrition expenditure group according to the study where they investigated income-expenditure relation of the students in Nottingham University. Compared to our study, it is seen that the highest share is the result of having a share of the food and secondly the food expenditure group has a similar result.

Chatterjee, Michelini, and Ray (1994) examined expenditure patterns and total consumer behavior in Australia and New Zealand. Demand models with demographic variables were estimated for nine horizontal sections in 1984 and 1988-89 for Australia and nine horizontal sections for 1984-91 for five horizontal groups in New Zealand.

Gergis (1995) investigated the structure of consumer preferences in Egypt and the distribution of household expenditures. The analysis was carried out by using the Linear Expenditure System (LES) and the Obstacle Curve estimation method with horizontal section data for 1964/65, 1974/75 and 1981/82 for 11 main commodities and 11 food subgroups.

Tan and Akdemir (1997) observed that the highest share of expenditure items belonged to nutrition expenditure with \%26,2 out of $619.000 \mathrm{TL}$ average income in the study where they searched the nutrition expenditure structure of the university students. According to the study, the monthly income of $\% 49,1$ of the students were not enough to regular nutrition, and as the income increased, while the share of nutrition, transportation, clothing, and beverage expenditure in total expenditures decreased, it was seen that expenditures related to culture services proportionately increased.

Özkan, Özçatalbaş and Akpınar (2000) observed the income and expenditure behaviors of the students in Akdeniz Agricultural Faculty sample. According to the findings of the study, the residential address of the student, the residential address and income of the family and the gender of the student took place in the factors affecting the consumption expenditures of the students. The highest share with $\% 42,8$ of expenditures belonged to nutrition, and it was comprehended that the income and expenditure equation was negative, and in case of increasing 1,4 times, they would have had adequate income. It was seen that the most determinative criterions in purchasing behaviors were quality and cheapness.

Ayyıldız and Toksoy (2002) searched socio-cultural structure effective on the income and the expenditures of the students of Forestry Faculty of Karadeniz Teknik University in Trabzon. According to the results of the study, they separated the highest share with $\% 23$ to nutrition, $\% 13,3$ to accommodation, $\% 18,4$ to transportation.

Akçaöz (2002) observed that the biggest income source of the students was the support of their families with \%41,1; and the first share in expenditure groups belonged to nutrition expenditures with $\% 61,2$ according to the results of the survey implemented to the Çukurova University students accommodating in student dormitory.

Butrica, Goldwyn, and Johnson (2005) included 8 expenditure groups, including housing, health, food, clothing, transportation, recreation, donation and other, in their study of income expenditure relations in the United States, with $29 \%$.

In the study of Tarı, Çalışkan and Bayraktar (2006) where the income-consumption relation of the students in Kocaeli University was analyzed, the total consumption functions of the students were primarily 
presumed. And then, the relation between nine different expenditure groups in the total consumptions of the students and income was analyzed by using Engel functions. Engel functions were separately presumed for all the students, males and females, and expenditure groups were separated as compulsory or luxury goods with the help of Engel functions. According to the findings of the study, it was observed that marginal propensity to consume of the male students is \%3,1 lower than the females', and the consumption behaviors of the students did not differ according to different education programs. The biggest share of the consumption budget of the students belonged to accommodation and nutrition; and then, respectively; communication, and transportation. The study is similar to our study with the highest expenditure share of having food and nutrition. In our study, the variable with the highest difference between marginal consumption tendencies is the residence variable, while the variable with the difference between the marginal consumption tendency is the residence variable.

Yaylalı et al. (2006) aimed to investigate the income-expenditure framework of the university youth in detail. For this purpose, they revealed the consumption expenditure habits and expenditure patterns of the university students with different demographic, social, and economic features in four-year high schools and faculties of state and foundation universities in Turkey. 9.909 surveys as sample size representing the universe of 1.117 .004 across Turkey were implemented. The prepared survey includes 41 basic close-ended and 113 special questions. Researchers acquired different findings by analyzing with expenditure items from various perspectives at the end of the study.

In his study, Zortuk (2009) investigated whether gender factor was effective on expenditure preferences or not through survey method implemented to the students of Dumlupınar University. First of all, the total consumption function of the students was presumed in the study, and then, the effect of the genders of the students on expenditure behaviors was searched. Also, the relation of 9 expenditure items with income was analyzed by using Engel functions.

Özer et al. (2010) conducted a survey to 900 students in their study where they investigated the income-expenditure relation of the students in Atatürk University and the contribution of the university students to the province economy and the total expenditure according to expenditure groups. According to the findings of the study including income elasticity with the help of Engel functions, out of 12 expenditure groups; nutrition, clothing-shoes, and accommodation groups were compulsory expenditures; other expenditure groups were compulsory expenditure, but their elasticity was approximate to unit elasticity; and chance game expenditures were luxury goods. When we look at our work, we found that income elasticity values for alcohol-tobacco, household goods, hotel-restaurant, luck games and sports expenditures are more than one and income elasticity values for other expenditure items are smaller than one.

In their study, Sevüktekin, Nargeleçekenler and Işın (2012) proposed to determine the socioeconomic profiles of the students in Uludağ University. Firstly, basic data was acquired by calculating descriptive statistics with data obtained from the surveys implemented in all the high schools and faculties of Uludağ University. Secondly, various findings were reached with the help of logistic regression analysis.

Demireli and Taşkın (2013) reached the end of that a student spends monthly average $495 \mathrm{TL}$ according to the results of the 3.285 surveys implemented to the Dumlupınar University students in Kütahya city center. It was observed that the highest share of the expenditure items of the students belonged to accommodation and nutrition expenditures.

Yayar and Çoban (2014) presumed Engel curves for expenditure groups taking place in the surveys implemented to the households in terms of urban area in Tokat province. According to the analysis results, it was observed that goods and services taking place in nutrition-nonalcoholic beverages, residence-water, electricity-other fuels and health expenditure groups were compulsory goods.

Altuntaş and Erilli (2015) implemented a survey study to the students in center campus of Cumhuriyet University. According to the results of the survey, the monthly average expenditure amount of a student studying in Cumhuriyet University was detected as 565,8 TL (rent-dorm excluded). 
When the literature is evaluated in general, it is similar to our study, that the marriage and nutrition expenditure groups have the highest share that the games of chance are necessities such as luxurious goods and hospitality, food, clothing shoes and so on.

\section{Data and Method}

A survey was implemented to the students of Amasya University so as to acquire data set of the study whose aim is to reveal the consumption expenditures of the university students and to investigate whether these expenditures are in relation with socio-demographic factors or not. Amasya University Center Campus includes 5 faculties, 4 vocational schools, 1 high school, and 2 institutes; and 11.580 registered students, 5501 female / 6079 male, form the universe of this study. The registered student numbers are stated according to programs and genders in Table 1.

Table 1. Distribution of the Students According to Academic Units and Genders

\begin{tabular}{lcccccc}
\hline \multirow{2}{*}{ Faculty/High School } & \multicolumn{2}{c}{ Female } & \multicolumn{2}{c}{ Male } & \multicolumn{3}{c}{ Total } \\
\cline { 2 - 7 } Faculty of Theology & Number & \% & Number & \% & Number & $\%$ \\
Design Vocational School (VS) & 171 & 60,21 & 113 & 39,79 & 284 & 100,00 \\
Health High School & 65 & 57,52 & 48 & 42,48 & 113 & 100,00 \\
\hline Faculty of Technology & 320 & 81,84 & 71 & 18,16 & 391 & 100,00 \\
\hline Faculty of Architecture & 84 & 14,41 & 499 & 85,59 & 583 & 100,00 \\
\hline Sabuncuoğlu Şerefeddin VS & 120 & 70,18 & 51 & 29,82 & 171 & 100,00 \\
\hline Faculty of Education & 1142 & 74,06 & 400 & 25,94 & 1542 & 100,00 \\
\hline Technical Sciences VS & 1655 & 66,39 & 838 & 33,61 & 2493 & 100,00 \\
\hline Social Sciences VS & 465 & 16,03 & 2435 & 83,97 & 2900 & 100,00 \\
\hline Faculty of Arts and Sciences & 908 & 46,59 & 1041 & 53,41 & 1949 & 100,00 \\
\hline Institute of Social Sciences & 355 & 63,85 & 201 & 36,15 & 556 & 100,00 \\
\hline Institute of Sciences & 117 & 34,62 & 221 & 65,38 & 338 & 100,00 \\
\hline Grand Total & 99 & 38,08 & 161 & 61,92 & 260 & 100,00 \\
\hline
\end{tabular}

Source: Amasya University Registrar's Office, 2016.

The surveys were implemented to the registered students in Amasya University during 2015-2016 academic years between 01.03 .2016 and 15.03 .2016 , and sampling method with probability proportional to size was used in selection of sample population. The sample size representing the relevant universe is \%1 significance level; even if it was calculated as approximately 400 surveys with $\% 5$ error margin, by thinking that some were not able to fulfill correctly, 800 students were conducted surveys, and 717 surveys were integrated to the analysis. Distribution were tried to be homogeneous as much as possible by proportioning the student number in each faculty-high school to the total number of the students in the survey implementation.

In the study, as a consumption classification, a sub-study of the National Accounts Classification, the Classification of Individual Consumption According to Purpose (COICOP), was used and the student expenditures were taken into consideration.

The survey implemented to determine the students' how to distribute their monthly average incomes among the expenditure groups consists of two sections. In the first section, personal information of the students takes place, and 14 expenditure items including food and nonalcoholic beverages, alcoholic beverages and tobacco, accommodation, household goods, health expenditures, transportation, communication, culture and enjoyment, education, clothing, various goods and services, hotel-restaurantbakery, chance games, and sport are available in the second section. Face to face survey method was used to collect data. 
The analysis of the study includes two parts; in the first part, collected data was used to presume the consumption functions of the students with the help of SPSS and Eviews programs. While consumption functions were formed, it was observed that whether gender of the students, education type ( daytime or evening education), getting scholarship/credit or not, being a student of faculty or high school, possession of credit card, studying in physical-social-health sciences, living in residence or dormitory formed a meaningful difference on consumption expenditures. In the second part, Engel curves (income elasticity) of expenditure groups were calculated.

In addition to using different functions in econometric analysis in presuming Engel Curves, 9 different templates used commonly in literature (Özer et al., 2010).

Table 2. Mathematical Functions

\begin{tabular}{lcc}
\hline Function name & Function template & Elasticity \\
\hline Linear & $\mathrm{C}=\mathrm{c}_{0}+\mathrm{c}_{1} \mathrm{Y}$ & $\mathrm{e}=\mathrm{c}_{1}(\mathrm{Y} / \mathrm{C})$ \\
Semi-log & $\ln \mathrm{C}=\mathrm{c}_{0}+\mathrm{c}_{1} \mathrm{Y}$ & $\mathrm{e}=\mathrm{c}_{1}(\mathrm{Y})$ \\
Semi-log & $\mathrm{C}=\mathrm{c}_{0}+\mathrm{c}_{1} \ln \mathrm{Y}$ & $\mathrm{e}=\mathrm{c}_{1}(1 / \mathrm{C})$ \\
Working-Leser & $\mathrm{C} / \mathrm{Y}=\mathrm{c}_{0}+\mathrm{c}_{1} \ln \mathrm{Y}$ & $\mathrm{e}=1+\mathrm{c}_{1}(\mathrm{Y} / \mathrm{C})$ \\
Inverse Function & $\mathrm{C}=\mathrm{c}_{0}-\mathrm{c}_{1}(1 / \mathrm{Y})$ & $\mathrm{e}=\mathrm{c}_{1}(1 / \mathrm{YC})$ \\
Duallog & $\ln \mathrm{C}=\mathrm{c}_{0}+\mathrm{c}_{1} \ln \mathrm{Y}$ & $\mathrm{e}=\mathrm{c}_{1}$ \\
Log Reverse & $\operatorname{lnC}=\mathrm{c}_{0}-\mathrm{c}_{1}(1 / \mathrm{Y})$ & $\mathrm{e}=\mathrm{c}_{1}(1 / \mathrm{Y})$ \\
Ratio linear & $\mathrm{C} / \mathrm{Y}=\mathrm{c}_{0}+\mathrm{c}_{1} \mathrm{Y}$ & $\mathrm{e}=1+\mathrm{c}_{1} \mathrm{Y}(\mathrm{Y} / \mathrm{C})$ \\
Ratio Reverse & $\mathrm{C} / \mathrm{Y}=\mathrm{c}_{0}-\mathrm{c}_{1}(1 / \mathrm{Y})$ & $\mathrm{e}=\mathrm{c}_{0}(\mathrm{Y} / \mathrm{C})$ \\
\hline
\end{tabular}

The function template in accord with the data among these templates was preferred. Among the mathematical templates above, $\mathrm{C}$ demonstrates the expenditure made for a specific good group; $\mathrm{Y}$ shows the income of the students; $E$ states the income elasticity of a certain expenditure group.

\section{Empirical Analysis}

\subsection{General Findings of the Study}

The monthly income and expenditures of the students, average values and standard deviations, minimum and maximum values of the variables and expenditure items are demonstrated in Table 3.

When Table 3 is observed, it can be seen that the monthly income of the students participating in the survey is $704,10 \mathrm{TL}$; their monthly expenditure is $607,15 \mathrm{TL}$. The first biggest share among the expenditure items belongs to accommodation expenditure with 198,76 TL, and second biggest share is food expenditure with 99,65 TL; and the smallest share is chance games with 3,98 TL. While the variable with the highest difference among marginal propensity to consume is variable of students getting scholarship-credit or not, the variable with the lowest difference among marginal propensity to consume is the variable of address. 
Table 3. Descriptive Statistics

\begin{tabular}{|c|c|c|c|c|c|}
\hline Definition of variables & $\begin{array}{l}\text { Variable } \\
\text { demonstration }\end{array}$ & Minimum & Maximum & Average & $\begin{array}{l}\text { Standard } \\
\text { deviation }\end{array}$ \\
\hline Monthly student income (TL) & $\mathrm{Y}$ & 100 & 3000 & 704,10 & 322,335 \\
\hline Monthly student expenditure (TL) & $\mathrm{C}$ & 100 & 2640 & 697,15 & 329,557 \\
\hline Nutrition & $\mathrm{C}_{\text {nutrition }}$ & 0 & 630 & 99,65 & 89,068 \\
\hline Alcohol- tobacco & $\mathrm{C}_{\text {alcohol }}$ & 0 & 600 & 58,74 & 109,349 \\
\hline Accommodation & $\mathrm{C}_{\text {accommodation }}$ & 0 & 850 & 198,76 & 155,632 \\
\hline Household goods & $\mathrm{C}_{\text {household goods }}$ & 0 & 250 & 8,37 & 24,260 \\
\hline Health & $\mathrm{C}_{\text {health }}$ & 0 & 150 & 9,30 & 18,961 \\
\hline Transportation & $\mathrm{C}_{\text {transportation }}$ & 0 & 400 & 51,65 & 50,401 \\
\hline Communication & $\mathrm{C}_{\text {communication }}$ & 0 & 300 & 34,66 & 33,531 \\
\hline Culture-enjoyment & $\mathrm{C}_{\text {culture }}$ & 0 & 300 & 36,03 & 40,470 \\
\hline Education & $\mathrm{C}_{\text {education }}$ & 0 & 224 & 48,14 & 51,376 \\
\hline Clothing-shoes & $\mathrm{C}_{\text {clothing }}$ & 0 & 355 & 62,29 & 60,780 \\
\hline Various goods and services & $\mathrm{C}_{\text {goods and services }}$ & 0 & 300 & 30,36 & 31,316 \\
\hline Hotel-restaurant & $\mathrm{C}_{\text {hotell }}$ & 0 & 500 & 45,84 & 60,229 \\
\hline Chance-games & $\mathrm{C}_{\text {chance }}$ & 0 & 250 & 3,98 & 17,441 \\
\hline Sport & $\mathrm{C}_{\text {sport }}$ & 0 & 160 & 9,38 & 23,785 \\
\hline $\begin{array}{l}\text { Physical or social sciences(if student of physical or health } \\
\text { sciences }=1 \text {; social sciences }=0 \text { ) }\end{array}$ & $\mathrm{D}_{1}$ & 0 & 1 & 47 & ,499 \\
\hline Faulty or VS(if student of Faculty-HS=1; VS=0) & $\mathrm{D}_{2}$ & 0 & 1 & ,51 &, 500 \\
\hline Gender (if male $=1$; female $=0$ ) & $\mathrm{D}_{3}$ & 0 & 1 &, 52 &, 500 \\
\hline Program type (daytime $=1$; evening $=0$ ) & $\mathrm{D}_{4}$ & 0 & 1 & 69 & ,461 \\
\hline Address (if house $=1$; dormitory $=0$ ) & $\mathrm{D}_{5}$ & 0 & 1 & ,43 & ,496 \\
\hline Scholarship-credit (if getting $=1$; not $=0$ ) & $\mathrm{D}_{6}$ & 0 & 1 & ,72 & ,451 \\
\hline Credit card (available $=1 ;$ not $=0$ ) & $\mathrm{D}_{7}$ & 0 & 1 & ,41 & ,493 \\
\hline $\begin{array}{l}\text { Difference among the marginal propensity to consume of } \\
\text { physical and social sciences students }\left(Y \times D_{1}\right)\end{array}$ & $Z_{1}$ & 0 & 3000 & 328,12 & 420,642 \\
\hline $\begin{array}{l}\text { Difference among the marginal propensity to consume of } \\
\text { Faculty and VS students }\left(Y \times D_{2}\right)\end{array}$ & $Z_{2}$ & 0 & 1800 & 350,74 & 397,399 \\
\hline $\begin{array}{l}\text { Difference among the marginal propensity to consume of } \\
\text { male and female students }\left(Y \times D_{3}\right)\end{array}$ & $Z_{3}$ & 0 & 2200 & 386,34 & 447,339 \\
\hline $\begin{array}{l}\text { Difference among the marginal propensity to consume of } \\
\text { daytime and evening education students }\left(Y \times D_{4}\right)\end{array}$ & $Z_{4}$ & 0 & 2200 & 451,76 & 379,885 \\
\hline $\begin{array}{l}\text { Difference among the marginal propensity to consume of the } \\
\text { students settling in house and dormitory }\left(Y \times D_{5}\right)\end{array}$ & $Z_{5}$ & 0 & 3000 & 313,36 & 431,748 \\
\hline $\begin{array}{l}\text { Difference among the marginal propensity to consume of the } \\
\text { students getting scholarship or } \operatorname{not}\left(Y \times D_{6}\right)\end{array}$ & $Z_{6}$ & 0 & 3000 & 513,15 & 420,745 \\
\hline $\begin{array}{l}\text { Difference among the marginal propensity to consume of the } \\
\text { students with credit card or } \operatorname{not}\left(Y \times D_{7}\right)\end{array}$ & $Z_{7}$ & 0 & 3000 & 328,44 & 454,629 \\
\hline Number of observations ( $n$ ) & 717 & & & & \\
\hline
\end{tabular}

VS: Vocational School and, HS: High School

\subsection{Total Consumption Expectations}

As a result of the literature review, it was found that Keynes' Expenditure model was the most preferred model in the studies examined and also the following linear function form which Keynes stated in his absolute income hypothesis was used to reveal the relation between the total consumption of the students and their incomes. 
To reveal the relation between total consumptions and incomes of the students, the linear function type below stated by Keynes in absolute income hypothesis was used.

$$
\mathrm{C}=\mathrm{c}_{0}+\mathrm{c}_{1} \mathrm{Y}
$$

In the Equation3 above,

C: Total consumption expenditure

$\mathrm{C}_{0}$ : Autonomous consumption

$\mathrm{Y}$ : Income

$\mathrm{c}_{1}$ : Marginal propensity to consume

In the study, firstly, it was investigated that whether there is difference between marginal propensity to consume and consumption expenditures of the students according to various features (education type, health-physical or social departments, faculty-high school or vocational school, getting scholarship-credit, possession of credit card and gender). In this research, in order to reveal the difference between marginal propensities to consume and consumption expenditures according to the relevant variables, shadow (dummy) variable consumption functions were presumed.

To reveal the difference between the marginal propensity to consume and consumption expenditures according to program type, the consumption function below was presumed.

$$
C_{i}=c_{0}+c_{1} Y_{i}+c_{2} D+c_{3} Z+u_{i}
$$

In this consumption function,

$\mathrm{C}_{\mathrm{i}}$ : monthly consumption expenditures of student $i$; $\mathrm{Y}_{\mathrm{i}}$ : monthly income of the student $\mathrm{i} ; \mathrm{D}$ : $(\mathrm{D}=0$ evening education, $D=1$ daytime education) program dummy variable; $Z:(Z=D \times Y)$ dummy variable showing the difference among marginal propensity to consume of the students of daytime and evening education.

Consumption function for evening education students;

$$
\begin{aligned}
& \mathrm{E}\left(\mathrm{C}_{\mathrm{i}} / \mathrm{D}=0\right)=\mathrm{c}_{0}+\mathrm{c}_{1} \mathrm{Y}_{\mathrm{i}}+\mathrm{c}_{2}(0)+\mathrm{c}_{3}\left(\mathrm{Y}_{\mathrm{i}} \times 0\right)+\mathrm{u}_{\mathrm{i}} \\
& \mathrm{C}_{\mathrm{i}}=\mathrm{c}_{0}+\mathrm{c}_{1} \mathrm{Y}_{\mathrm{i}}+\mathrm{u}_{\mathrm{i}}
\end{aligned}
$$

Consumption functions for daytime education students;

$$
\begin{aligned}
& E\left(C_{i} / D=1\right)=c_{0}+c_{1} Y_{i}+c_{2}(1)+c_{3}\left(Y_{i} \times 1\right)+u_{i} \\
& C_{i}=\left(c_{0}+c_{2}\right)+\left(c_{1}+c_{3}\right) Y_{i}+u_{i}
\end{aligned}
$$

Presumed model result is like below, and it is given as Model 4 in Table 4.

$$
\mathrm{C}=134,1+0,85 \mathrm{Y}-86,57 \mathrm{D}_{4}+0,05 \mathrm{Z}_{4}
$$


The Econometric Analysis of Student Expenditures: A Case Study of Amasya University

Table 4. Consumption Expenditures and Marginal Propensity to Consume According to the Different Features of the Students

\begin{tabular}{|c|c|c|c|c|c|c|c|c|}
\hline Models & & $\mathbf{c}_{0}^{+}$ & $\mathbf{c}_{1}{ }^{+}$ & $\mathrm{D}_{1}{ }^{+}$ & $\mathrm{Z}_{1}^{+}$ & $\mathbf{R}^{2}$ & $F$ & $\mathrm{DW}^{++}$ \\
\hline \multirow{3}{*}{$\begin{array}{l}\text { Model 1: physical - health or } \\
\text { social sciences } \\
\qquad\left[C=c_{0}+c_{1} Y+D_{1}+Z_{1}\right]\end{array}$} & Model 1a & $\begin{array}{l}51,40^{*} \\
{[2,28]}\end{array}$ & $\begin{array}{c}0,94^{* *} \\
{[26,64]}\end{array}$ & $\begin{array}{l}22,55 \\
{[0,74]}\end{array}$ & $\begin{array}{c}-0,08 \\
{[-1,54]}\end{array}$ & 0,78 & 821,65 & $\begin{array}{c}2,01 \\
{[0,13]}\end{array}$ \\
\hline & Model 1b & $\begin{array}{c}79,58^{* *} \\
{[4,61]}\end{array}$ & $\begin{array}{c}0,90^{* *} \\
{[35,39]}\end{array}$ & $\begin{array}{c}-31,53^{* *} \\
{[-2,66]}\end{array}$ & - & 0,77 & 1224,28 & $\begin{array}{c}2,00 \\
{[0,15]}\end{array}$ \\
\hline & Model 1c & $\begin{array}{c}62,96^{* *} \\
{[4,13]}\end{array}$ & $\begin{array}{c}0,92^{* *} \\
{[35,93]}\end{array}$ & - & $\begin{array}{l}-0,05^{* *} \\
{[-2,53]}\end{array}$ & 0,78 & 1232,78 & $\begin{array}{c}2,00 \\
{[0,14]}\end{array}$ \\
\hline \multirow{3}{*}{$\begin{array}{l}\text { Model 2: Faculty - high school or } \\
\text { vocational school } \\
{\left[C=c_{0}+c_{1} Y+D_{2}+Z_{2}\right]}\end{array}$} & Model 2a & $\begin{array}{l}67,76^{* *} \\
{[3,35]}\end{array}$ & $\begin{array}{l}0,88^{* *} \\
{[25,44]}\end{array}$ & $\begin{array}{l}-16,51 \\
{[-0,56]}\end{array}$ & $\begin{array}{c}0,05 \\
{[1,03]}\end{array}$ & 0,88 & 810,15 & $\begin{array}{c}1,99 \\
{[0,10]}\end{array}$ \\
\hline & Model 2b & $\begin{array}{c}55,10^{* *} \\
{[3,69]}\end{array}$ & $\begin{array}{c}0,90^{* *} \\
{[35,59]}\end{array}$ & $\begin{array}{l}17,53 \\
{[1,51]}\end{array}$ & - & 0,90 & 1213,33 & $\begin{array}{c}1,98 \\
{[0,09]}\end{array}$ \\
\hline & Model 2c & $\begin{array}{l}61,15^{* *} \\
{[4,12]}\end{array}$ & $\begin{array}{c}0,89^{* *} \\
{[31,56]}\end{array}$ & - & $\begin{array}{c}0,03 \\
{[1,53]}\end{array}$ & 0,77 & 1216,23 & $\begin{array}{c}1,98 \\
{[0,10]}\end{array}$ \\
\hline \multirow{3}{*}{$\begin{array}{l}\text { Model 3: Gender } \\
{\left[C=\mathbf{c}_{0}+\mathbf{c}_{1} \mathbf{Y}+\mathbf{D}_{3}+\mathbf{Z}_{3}\right]}\end{array}$} & Model 3a & $\begin{array}{l}71,02^{* *} \\
{[3,85]}\end{array}$ & $\begin{array}{c}0,88^{* *} \\
{[27,79]}\end{array}$ & $\begin{array}{c}-7,06 \\
{[-0,24]}\end{array}$ & $\begin{array}{c}0,03 \\
{[0,57]}\end{array}$ & 0,77 & 806,68 & $\begin{array}{c}1,98 \\
{[0,10]}\end{array}$ \\
\hline & Model 3b & $\begin{array}{c}60,25^{* *} \\
{[3,64]}\end{array}$ & $\begin{array}{c}0,90^{* *} \\
{[35,24]}\end{array}$ & $\begin{array}{l}11,72 \\
{[1,02]}\end{array}$ & - & 0,77 & 1210,59 & $\begin{array}{c}1,98 \\
{[0,10]}\end{array}$ \\
\hline & Model 3c & $\begin{array}{l}67,21^{* *} \\
{[4,42]}\end{array}$ & $\begin{array}{c}0,88^{* *} \\
{[34,08]}\end{array}$ & - & $\begin{array}{c}0,02 \\
{[0,98]}\end{array}$ & 0,77 & 1211,59 & $\begin{array}{c}1,98 \\
{[0,11]}\end{array}$ \\
\hline \multirow{3}{*}{$\begin{array}{l}\text { Model 4: Program type } \\
{\left[C=c_{0}+c_{1} Y+D_{4}+Z_{4}\right]}\end{array}$} & Model 4a & $\begin{array}{c}134,15^{* *} \\
{[4,52]}\end{array}$ & $\begin{array}{c}0,85^{* *} \\
{[21,71]}\end{array}$ & $\begin{array}{l}-86,58^{*} \\
{[-2,43]}\end{array}$ & $\begin{array}{c}0,05 \\
{[0,96]}\end{array}$ & 0,78 & 827,37 & $\begin{array}{c}1,99 \\
{[0,11]}\end{array}$ \\
\hline & Model 4b & $\begin{array}{c}110,71^{* *} \\
{[5,02]}\end{array}$ & $\begin{array}{c}0,88^{* *} \\
{[32,98]}\end{array}$ & $\begin{array}{c}-48,59^{* *} \\
{[-3,36]}\end{array}$ & - & 0,78 & 1238,73 & $\begin{array}{c}1,99 \\
{[0,13]}\end{array}$ \\
\hline & Model 4c & $\begin{array}{l}75,66^{* *} \\
{[4,42]}\end{array}$ & $\begin{array}{c}0,91^{* *} \\
{[33,58]}\end{array}$ & - & $\begin{array}{l}-0,04^{*} \\
{[-2,02]}\end{array}$ & 0,77 & 1225,55 & $\begin{array}{c}1,99 \\
{[0,15]}\end{array}$ \\
\hline \multirow{3}{*}{$\begin{array}{l}\text { Model 5: Address } \\
{\left[C=c_{0}+c_{1} Y+D_{5}+Z_{5}\right]}\end{array}$} & Model 5a & $\begin{array}{c}80,30^{* *} \\
{[3,15]}\end{array}$ & $\begin{array}{c}0,88^{* *} \\
{[21,47]}\end{array}$ & $\begin{array}{l}-30,52 \\
{[-0,95]}\end{array}$ & $\begin{array}{c}0,04 \\
{[0,69]}\end{array}$ & 0,77 & 806,18 & $\begin{array}{c}1,97 \\
{[0,12]}\end{array}$ \\
\hline & Model 5b & $\begin{array}{c}66,55^{* *} \\
{[4,01]}\end{array}$ & $\begin{array}{c}0,90^{* *} \\
{[35,10]}\end{array}$ & $\begin{array}{c}-5,09 \\
{[-0,42]}\end{array}$ & - & 0,77 & 1208,85 & $\begin{array}{c}1,97 \\
{[0,09]}\end{array}$ \\
\hline & Model 5c & $\begin{array}{c}64,70^{* *} \\
{[4,05]}\end{array}$ & $\begin{array}{l}0,90^{* *} \\
31,42\end{array}$ & - & $\begin{array}{c}0,0003 \\
{[0,02]}\end{array}$ & 0,77 & 1208,41 & $\begin{array}{c}1,97 \\
{[0,08]}\end{array}$ \\
\hline \multirow{3}{*}{$\begin{array}{l}\text { Model 6: Scholarship-credit } \\
{\left[C=c_{0}+c_{1} Y+D_{6}+Z_{6}\right]}\end{array}$} & Model 6a & $\begin{array}{c}98,42^{* *} \\
{[3,50]}\end{array}$ & $\begin{array}{c}0,84^{* *} \\
{[16,58]}\end{array}$ & $\begin{array}{l}-49,17 \\
{[-1,44]}\end{array}$ & $\begin{array}{c}0,08 \\
{[1,34]}\end{array}$ & 0,77 & 810,49 & $\begin{array}{c}1,98 \\
{[0,13]}\end{array}$ \\
\hline & Model 6b & $\begin{array}{c}61,42^{* *} \\
{[3,77]}\end{array}$ & $\begin{array}{c}0,90^{* *} \\
{[34,67]}\end{array}$ & $\begin{array}{c}4,97 \\
{[0,37]}\end{array}$ & - & 0,77 & 1208,77 & $\begin{array}{c}1,97 \\
{[0,09]}\end{array}$ \\
\hline & Model 6c & $\begin{array}{l}65,11^{* *} \\
{[4,13]}\end{array}$ & $\begin{array}{l}0,88^{* *} \\
{[25,94]}\end{array}$ & - & $\begin{array}{c}0,02 \\
{[0,85]}\end{array}$ & 0,77 & 1211,61 & $\begin{array}{c}1,98 \\
{[0,10]}\end{array}$ \\
\hline \multirow{3}{*}{$\begin{array}{l}\text { Model 7: Credit card } \\
{\left[C=c_{0}+c_{1} Y+D_{7}+Z_{7}\right]}\end{array}$} & Model 7a & $\begin{array}{c}65,41^{* *} \\
{[3,54]}\end{array}$ & $\begin{array}{c}0,88^{* *} \\
{[27,38]}\end{array}$ & $\begin{array}{l}19,48 \\
{[0,60]}\end{array}$ & $\begin{array}{c}0,02 \\
{[0,32]}\end{array}$ & 0,77 & 814,11 & $\begin{array}{c}1,98 \\
{[0,07]}\end{array}$ \\
\hline & Model 7b & $\begin{array}{c}59,81^{* *} \\
{[3,75]}\end{array}$ & $\begin{array}{c}0,89^{* *} \\
{[34,72]}\end{array}$ & $\begin{array}{c}30,97^{* *} \\
{[2,56]}\end{array}$ & - & 0,77 & 1222,46 & $\begin{array}{c}1,97 \\
{[0,07]}\end{array}$ \\
\hline & Model 7c & $\begin{array}{c}73,78^{* *} \\
{[4,73]}\end{array}$ & $\begin{array}{c}0,87^{* *} \\
{[31,99]}\end{array}$ & - & $\begin{array}{l}0,04^{*} \\
{[1,98]}\end{array}$ & 0,77 & 1221,90 & $\begin{array}{c}1,98 \\
{[0,08]}\end{array}$ \\
\hline
\end{tabular}

${ }^{* *}$ and ${ }^{*}$ respectively demonstrates the significance at $\% 1$ and \%5level.

${ }^{+}$The values in parenthesis are $t$ values belong to the coefficients.

${ }^{++}$The values in parenthesis demonstrate Breusch-Godfrey Serial Correlation LM Test significance level. $(p>0,05$ nonautocorrelation; $p \leq 0,05$ autocorrelation).

According to expectation results, the coefficients of $c_{0}$ and $c_{1}$ at $\% 5$ significance level, $c_{2}$ at $\% 1$ significance level were found statistically meaningful, and the coefficient of $c_{3}$ belonging to $Z_{4}$ dummy variable was not found statistically meaningful. According to this result, it can be said that there is meaningful 
difference in terms of statistics between the expenditures of daytime and evening education students. However, it was observed that there was not a meaningful difference between the marginal propensity to consume of daytime and evening education students. $Z_{4}$ Dummy variable, given place in Model 4a; however, not found statistically meaningful, was taken out of the model, and a new model (Model 4b) was formed. All the coefficients, $c_{0}, c_{1}$, ve $c_{2}$, were found meaningful at $\% 5$ significance level according to the new model obtained. Namely, the difference between the expenditures of the students in daytime and evening education was determined thanks to higher $\mathrm{F}$ and $\mathrm{t}$ tests. And then, so as to comprehend that whether marginal propensity to consume differed or not according to programs, a third model (Model 4c) was formed by omitting $\mathrm{D}_{4}$ dummy variable from the model. In the new model, the coefficients of $\mathrm{c}_{0}, \mathrm{c}_{1}$, andc $\mathrm{c}_{3}$ were observed as meaningful at \%5 significance level. According to Model 4c, occurrence of important differences between the marginal propensities to consume of the students in daytime and evening education can be expressed. According to Model $4 a$, it can be said that the autonomous consumption of the students in evening education is $134,1 \mathrm{TL}$, and marginal propensity to consume is 0,85 . According to Model 4 a, while anything specific related to marginal propensity to consume of the students in daytime education cannot be said, it can be said that the autonomous consumption of the students in daytime education $(47,5 \mathrm{TL})$ is lower than the students' in evening education.

Whether there was a difference between marginal propensity to consume and consumption expenditures of the students was calculated through the same method, and the results were given in Table 4. The interpretation of the regression equation let to the reader. In the models in Table 4, suitable function type was preferred as linear template thanks to the conformity in terms of econometric and statistics and the interpretation in an easy way.

Expected econometric models are used for structural analysis, economic policy-making, and forecasts. In case of usage of expectations for forecast, heteroscedasticity is an important problem (Özer et al., 2010:243). Although the basic purpose of this study was thought as structural analysis, heteroscedasticity problem was tried to be eliminated. Heteroscedasticity problem in all the regression equations was detected; it was adjusted through variance-covariance matrix developed by White.

The relation among repented values of disturbance term is defined as autocorrelation (Akkaya and Pazarlıoglu, 1995). In the interpretation of the coefficients related to models with autocorrelation problem, it is necessary to be careful. The presence of autocorrelation problem in the models above was investigated through Durbin-Watson and Breusch-Godfrey Serial Correlation LM Test statistics, and it was detected that there was not such a problem in all of the models.

The presence of entire or nearly entire linear relation among the whole or some of explanatory variables in a regression model is defined as multicollinearity. This relevant situation is not wanted in regression models. Multicollinearity in the models given in Table 4 was investigated, and it was conducted that there was not multicollinearity problem in all the models by looking at the Variance Inflation Factor (VIF) values.

\subsection{Income Elasticity of Expenditure Groups}

To be able to find general expenditure equation and functions belonging to expenditure groups, 5 (linear, log-linear, linear-log, entire log, and working-leser) functional templates are known to be frequently used in application. Function templates suitable for the relevant data were experimented one by one for each expenditure group in this study. The most suitable function templates were selected by evaluating obtained equations in terms of statistics and econometric. Acquired results from these models are given in Table 5. 
The Econometric Analysis of Student Expenditures: A Case Study of Amasya University

\begin{tabular}{|c|c|c|c|c|}
\hline Expenditure groups & Functions $^{+}$ & $\mathbf{R}^{2}$ & $\mathrm{DW}^{++}$ & Elasticity \\
\hline General & $\begin{array}{r}\ln C_{\text {general }}=0,41+0,93 \ln Y_{i} \\
{[3,19][47,35]}\end{array}$ & 0,76 & $\begin{array}{c}2,01 \\
{[0,08]}\end{array}$ & $e=0,93$ \\
\hline Nutrition & $\begin{array}{r}\mathrm{C}_{\text {nutrition }}=0,59+0,14 Y_{\mathrm{i}} \\
{[0,07][11,31]}\end{array}$ & 0,26 & $\begin{array}{c}1,78 \\
{[0,02]}\end{array}$ & $e=0,99$ \\
\hline Alcohol-tobacco & $\begin{array}{r}\mathrm{C}_{\text {alcohol }}=-59,03+0,17 \mathrm{Y}_{\mathrm{i}} \\
{[-5,84][10,09]}\end{array}$ & 0,24 & $\begin{array}{c}1,73 \\
{[0,01]}\end{array}$ & $e=1,92$ \\
\hline Accommodation & $\begin{array}{c}\mathrm{C}_{\text {accommodation }}=-1113,21+202,96 \ln \mathrm{Y}_{\mathrm{i}} \\
{[-13,38][15,41]}\end{array}$ & 0,31 & $\begin{array}{c}1,84 \\
{[0,01]}\end{array}$ & $e=0,0014$ \\
\hline Household goods & $\begin{array}{r}\mathrm{C}_{\text {household goods }}=-5,10+0,02 \mathrm{Y}_{\mathrm{i}} \\
{[-1,56][3,61]}\end{array}$ & 0,06 & $\begin{array}{c}2,00 \\
{[0,27]}\end{array}$ & $e=1,60$ \\
\hline Health & $\begin{array}{c}\mathrm{C}_{\text {health }}=-8,229+2,711 \operatorname{lnYi} \\
{[-0,72][1,50]}\end{array}$ & 0,01 & $\begin{array}{c}1,88 \\
{[0,28]}\end{array}$ & $\mathrm{e}=0,0004$ \\
\hline Transportation & $\begin{array}{r}C_{\text {transportation }}=-101,75+23,730 \ln Y \mathrm{i} \\
{[-3,27][4,83]}\end{array}$ & 0,04 & $\begin{array}{c}1,77 \\
{[0,00]}\end{array}$ & $\mathrm{e}=0,0006$ \\
\hline Communication & $\begin{array}{r}\mathrm{C}_{\text {communication }}=13,117+0,031 \mathrm{Y}_{\mathrm{i}} \\
{[8,26][-6,42]}\end{array}$ & 0,09 & $\begin{array}{c}1,86 \\
{[0,10]}\end{array}$ & $\mathrm{e}=0,63$ \\
\hline Culture-enjoyment & $\begin{array}{l}\mathrm{C}_{\text {culture }}=8,52+0,03 \mathrm{Y}_{\mathrm{i}} \\
{[2,22][6,46]}\end{array}$ & 0,10 & $\begin{array}{c}2,02 \\
{[0,40]}\end{array}$ & $\mathrm{e}=0,76$ \\
\hline Education & $\begin{aligned} \mathrm{C}_{\text {education }}= & -90,1+21,38 \ln \mathrm{Y}_{\mathrm{i}} \\
& {[-3,25][4,92] }\end{aligned}$ & 0,03 & $\begin{array}{c}1,04 \\
{[0,00]}\end{array}$ & $\mathrm{e}=0,001$ \\
\hline Clothing-shoes & $\begin{array}{c}\mathrm{C}_{\text {clothing }}=31,1+0,044 \mathrm{Y}_{\mathrm{i}} \\
{[5,91][5,47]}\end{array}$ & 0,06 & $\begin{array}{c}1,93 \\
{[0,51]}\end{array}$ & $\mathrm{e}=0,50$ \\
\hline $\begin{array}{l}\text { Various goods and } \\
\text { services }\end{array}$ & $\begin{array}{r}C_{\text {goods and services }}=12,342+0,026 Y_{i} \\
{[4,46][5,81]}\end{array}$ & 0,07 & $\begin{array}{c}1,83 \\
{[0,04]}\end{array}$ & $\mathrm{e}=0,60$ \\
\hline Hotel-restaurants & $\begin{array}{r}C_{\text {hotell }}=-4,45+0,07 Y_{\mathrm{i}} \\
{[-0,78][7,44]}\end{array}$ & 0,15 & $\begin{array}{c}1,89 \\
{[0,31]}\end{array}$ & $\mathrm{e}=1,08$ \\
\hline Chance games & $\begin{array}{r}C_{\text {chance }}=-5,01+0,013 Y_{i} \\
{[-2,90][4,16]}\end{array}$ & 0,06 & $\begin{array}{c}2,00 \\
{[0,99]}\end{array}$ & $e=2,30$ \\
\hline Sport & $\begin{array}{r}C_{\text {sport }}=-3,577+0,018 Y_{i} \\
{[-1,81][5,75]}\end{array}$ & 0,06 & $\begin{array}{c}{[1,91]} \\
0,36\end{array}$ & $\mathrm{e}=1,35$ \\
\hline
\end{tabular}

+The values in parenthesis are t values belong to the coefficients.

${ }^{++}$The values in parenthesis demonstrateBreusch-GodfreySerialCorrelation LM Test significance level. ( $p>0,05$ non-autocorrelation; $\mathrm{p} \leq 0,05$ autocorrelation).

As seen in Table 5, it was determined that semi-log form for accommodation, health, transportation, and education expenditures; linear form for other expenditure groups were suitable. Also, that the most suitable form for general expenditure and income was logarithmic functional template was presumed.

The presence of heteroscedasticity in presumed models in Table 5 was investigated through White test. As the results of the test, presumed 15 models, general, health, communication, various goods and services, chance games, and sport, did not include heteroscedasticity; it was detected that the rest 9 models contained heteroscedasticity.

The presence of autocorrelation problem in the models in Table 5 was investigated through DurbinWatson and Breusch-Godfrey Serial Correlation LM Test statistics. When the Table 5 was observed, it was determined that equations belonging to general consumption, household goods, health, communication, culture-enjoyment, clothing-shoes, hotel, chance games, and sport expenditures did not include autocorrelation, and that there was autocorrelation in other equations. In the interpretation of the disturbance term of the models including autocorrelation, it is necessary to be careful.

As stated before, while the relation between consumption expenditures and income is explained, if income elasticity is negative $(e<0)$, that good is evaluated as inferior good; if positive (e>0), as normal good; if between 0 and $1(0<e>1)$, as compulsory good; if higher than 1 (e>1), as luxury good (Yaylalı, 2004). On 
observing Table 5, it was determined that food, accommodation, health, transportation, communication, culture-enjoyment, education, clothing, goods and services expenditures are compulsory expenditures; that alcohol, household goods, hotel-restaurant, chance games, and sport expenditures are luxury expenditures. Similarly, Özer et al. (2010) tried to presume 12 expenditure groups in terms of income elasticity in their study. They presumed food, clothing, and accommodation expenditures as compulsory expenditures; transportation, communication, personal care, education, enjoyment, socio cultural, alcoholic beverages, tobacco and tobacco product, and other expenditures as compulsory expenditures; however, they were approximate to unit elasticity; and chance games expenditures as luxury goods.

\section{Conclusion}

In this study, consumption expenditures of the students, one of the important income sources in regional economy, were revealed, and it was investigated whether these expenditures are in relation with socio-demographic factors or not. To realize this purpose, survey was implemented to 800 students.

The average income of the students is $704,10 \mathrm{TL}$, and the average expenditure is $697,15 \mathrm{TL}$. The average monthly saving is 6, $95 \mathrm{TL}$. The average food expenditure of the students is $99,65 \mathrm{TL}$; alcohol-tobacco expenditure is 58,74 TL; 198,76 TL for accommodation; 8,37 TL for household goods; 9,30 TL for health, 51,65 TL for transportation; 34,66 TL for communication; 36,03 TL for culture-enjoyment; 48,14 TL for education; 62,29 TL for clothing-shoes; 30,36 TL for various goods and services; 45,84 TL for hotel-restaurant; 3,98 TL for chance games; and 9,38 TL for sport.

The presence of the difference between the consumption expenditure and marginal propensity to consume of the students was investigated according to program type, health-physical or social departments, faculty-high school or vocational school, getting scholarship-credit, possession of credit card, and gender, and to be able to reveal the difference between consumption expenditures and marginal propensity to consume for each variable, consumption functions were presumed through dummy variable. Consequently, to reveal the presence of difference between the marginal propensity to consume and consumption expenditures of the students according to program type, 3 different models were formed. As a result, while it can be stated that there is a meaningful difference among the expenditures of the students in daytime and evening education in the first model, it is obtained that there is not a meaningful difference among marginal propensity to consume. In the second model formed by omitting $Z$ dummy variable, the difference among the expenditures of the students in daytime and evening education was determined, and in order to comprehend whether the marginal propensity to consume differs or not according to the programs, a third model was formed by omitting $D$ dummy variable. According to the last form, it can be said that there are important differences among the marginal propensity to consume of the students in daytime and evening education. It can also be stated that the autonomous consumption of the students in evening education is $134,1 \mathrm{TL}$, and that marginal propensity to consume is 0,85 . While a certain thing related to the marginal propensity to consume of the students in daytime education cannot be said, it can be expressed that their autonomous consumption is $47,5 \mathrm{TL}$ lower than the students' in evening education. The regression equations calculated according to the other features of the students are presented in Table 4.

Income elasticity of expenditure groups were tried to be presumed through 3 different functional templates in the study. Semi-log for accommodation, health, transportation, and education expenditures; and linear for the other expenditure groups were presumed as suitable functional template. Also, the most suitable one for general expenditure and income was presumed as entire logarithmic functional template.

Income-expenditure relation in terms of 14 expenditure groups, income elasticity was tried to be presumed through Engel functions. Consequently, it was observed that income elasticity values related to alcohol-tobacco, household goods, hotel-restaurant, chance games, and sport expenditures are higher than 1 ; that income elasticity values related to the other expenditure items are lower than 1. 


\section{End Notes}

1. The abstract of the study was presented at the $17^{\text {th }}$ International Symposium on Econometrics, Operations Research and Statistics.

\section{References}

Akçaöz, H. (2002). Üniversite yurt öğrencilerinin gıda tüketim harcamalarının yapısı ve sorunları. Pazarlama Dünyası, 16(2), 48-51.

Akkaya, Ş., \& Pazarlıŏlu, M. V. (1995), Ekonometri I, 3. Baskı, Anadolu Matbaacılık, İzmir.

Altunöz, U. (2014). Tüketim fonksiyonu ve Türkiye için gelir-tüketim ilişkisinin ampirik analizi. International Conference of Eurasian Economies.

Altuntaş, C., \& Erilli, N. A. (2015). Cumhuriyet Üniversitesinin Sivas ili ekonomisine katkısı. Siirt Üniversitesi iktisadi ve Idari Bilimler Dergisi, 3(1), 11-20.

Ayyıldız, H., \& Toksoy, D. (2002). Üniversite öğrencilerinin sosyal kültürel özellikleri ve gelir harcama yapısı: Karadeniz Teknik Üniversitesi Orman Fakültesi örneği. Pazarlama Dünyası, 16(6), 50-57.

Belaney, M.F., Binks, M.R., Greenaway, D., Reed, G.V., \& Whynes, D.K. (1992). What does a university add to its local economy. Applied Economics, 24, 305-311.

Butrica, B.A., Joshua, H.G, \& Richard, W.J. (2005). Understanding expenditure patterns in retirement. CRR Working Paper, No.2005-03, 1-41.

Chatterjee, S., Michelini, C., \& Ray, R. (1994). Expenditure patterns and aggregate consumer behavior: Some experiment with Australian and New Zealand data. Economic Record, 70(210), 278-291.

David, C. (2003). Universities and territorial development: Reshaping the regional role of UK universities. Local Economy, 18 (1), 7-20.

Demireli, C., \& Taşkın, E. (2013). Üniversite öğrencilerinin bulundukları şehre ekonomik katkıları: Kütahya il merkezi örneği. Dumlupınar Üniversitesi Sosyal Bilimler Dergisi, 37, 321-328.

Dougles, M., \& Isherwood, B. (1999). Tüketimin antropolojisi. (Çev: E. Atilla Aytekin). Ankara: DostKitabevi.

Dussenbery, J. (1949). Income, saving and theory of consumer behavior. Harward University Press, Cambridge

Eren, E. (2001). Makroiktisat. İstanbul: Avcıol Basım Yayım.

Ferber, R. (1962). Research on household behaviour. The American Economic Review, 52(1), 19-63.

Friedman, M. (1957). A Theory of the Consumption Function. National Bureau of Economic Research, Newyork

Gergis, A. T. (1995). Household consumption analysis: Patterns behavior and distribution in Egypt. Boston University Graduate School (Unpublished Ph. D. Dissertation), Boston.

Giles, D. E. A., \& Hampton, P. (1985). An Engel curve analysis of household expenditure in New Zealand. Economic Record, 61(1), 450-462.

Houthakker, H.S. (1957). An international comparision of household expenditure patterns, commemoratig the centenary of Engel's Law. Econometrica, 25(4), 532-551.

Keynes, J.M. (1969). İstihdam, faiz ve para genel teorisi. Çev: Asım Baltacıgil, Fakülteler Matbaası, ìstanbul

Modigliani, F., \& Ando, A. (1963).The life sycle hypothesis of saving: Aggregated implications and tests. American Economic Review, 53, 55-84.

Özer, H., Akan, Y., \& Çalmaşur, G. (2010). Atatürk Üniversitesi öğrencilerinin gelir-harcama ilişkisi. C.Ü. Iktisadi ve idari Bilimler Dergisi, 11(1), 231-249.

Özkan, B., Özçatalbaş, O., \& Akpınar, G. (2000). Üniversite öğrencilerinin gelir ve harcama yapısı: Akdeniz Ziraat Fakültesi Örneği. Pazarlama Dünyası, 14(79), 4-9.

Paya, M. (2007). Makroiktisat. İstanbul: Filiz Kitabevi.

Sachs, D.J., \& Larrain, F. B. (1993). Macroeconomics in the global economy. New York: Harvester Wheatsheaf.

Sevüktekin, M., Nargeleçekenler, M., \& Işın, Ç. (2012). Uludağ Üniversitesi öğrencilerinin sosyo-ekonomik profil araştirması. Uludağ Üniversitesi iktisadi ve idari Bilimler Fakültesi Dergisi, XXXI (2), 99-128.

Tan, A., \& Akdemir, Ş. (1997). Üniversite öğrencilerinin gıda tüketim harcamalarının yapısı ve sorunları. Pazarlama Dünyası, 64, 22-27. 
Tarı, R., Çalışkan, Ş., \& Bayraktar, Y. (2006). Kocaeli Üniversitesi öğrencilerinin gelir ve tüketim ilişkisi üzerine ekonometrik bir inceleme. Kocaeli Üniversitesi Sosyal Bilimler Enstitüsü Dergisi, 11(1), 168-179.

Ünsal, E. (2007). Makrolktisat. Ankara: İrem Yayıncılık.

Yayar, R., \& Çoban, N.M. (2014). tokat ili kentsel alanda Engel eğrisi analizi. Eskişehir Osmangazi Üniversitesi iiBF Dergisi, 9(3), 95-105.

Yaylalı, M. (2004). Mikroiktisat. İstanbul: Beta Yayınları.

Zortuk, M. (2009). Cinsiyet değişkeni bağlamında harcama alt grupları ve gelir ilişkisi: Dumlupınar Üniversitesi öğrencileri üzerine bir uygulama. Dumlupınar Üniversitesi Sosyal Bilimler Dergisi, 23,25-32.

Wilson, J. H. (1975). The student expenditure impact of a university on the local economy. The Annal of Regional Science, 9(1), 122-126. 
This Page Intentionally Left Blank 